\title{
Simulation model of the growth of sweet orange (Citrus sinensis L. Osbeck) cv. Natal in response to climate change
}

\author{
Francisca Franciana Sousa Pereira ${ }^{1}$ (ID) \\ Rodrigo Máximo Sánchez-Román ${ }^{1}$. \\ Alba María Guadalupe Orellana González ${ }^{1}$
}

Received: 12 May 2016 / Accepted: 3 May 2017 / Published online: 16 May 2017

(C) Springer Science+Business Media Dordrecht 2017

\begin{abstract}
The objective of the present study was to develop a simulation model of the growth of sweet orange (Citrus sinensis L. Osbeck) cv. Natal in response to climate change based on system dynamics principles. The model was developed based on a system analysis of the factors that affect crop biomass formation. The main variables considered were atmospheric carbon dioxide $\left(\mathrm{CO}_{2}\right)$, air temperature, transpiration, rainfall, water deficit, irrigation depth, canopy volume, and the respective interrelationships. Simulations were performed for the period from 2010 to 2100 . Overall, the model results indicate that the increase in atmospheric $\mathrm{CO}_{2}$ concentrations predicted in the Intergovernmental Panel on Climate Change (IPCC) report, combined with air temperatures higher, lower, or equal to those generally occurring in natural environments, will result in higher water use efficiency by orange trees. When other factors, such as the soil water deficit, were included in the model, the water productivity was predicted to be lower in 2100 without irrigation than when irrigation was included. It is concluded that the model is suitable for determination of the effects of climate change on water use efficiency of sweet orange cv. Natal. Increased atmospheric $\mathrm{CO}_{2}$ concentrations will result in higher $\mathrm{CO}_{2}$ assimilation in orange trees and therefore in increased biomass production $(\mathrm{g})$ per unit of water transpired $(\mathrm{mm})$. However, this positive effect may be masked by other effects of atmospheric $\mathrm{CO}_{2}$ increases, mainly those associated with temperature.
\end{abstract}

\section{Introduction}

Climatic change is mainly a result of high concentrations of greenhouse gases in the atmosphere. According to data from the Intergovernmental Panel on Climate Change (IPCC 2014), atmospheric carbon dioxide $\left(\mathrm{CO}_{2}\right)$ concentrations have increased considerably between 1750

Rodrigo Máximo Sánchez-Román rmsroman@fca.unesp.br 
and 2011 by approximately $40 \%$, with a trend toward that further increases in the future (Stich et al. 2008; IPCC 2014).

Assimilation of $\mathrm{CO}_{2}$ by crops is affected by several factors. Water availability has been reported to be the main factor affecting $\mathrm{CO}_{2}$ assimilation by crops (Delgado et al. 2010). However, under adequate water conditions, photosynthesis of orange trees throughout the year is mainly affected by variations in the air and soil temperature, the day length, and, obviously, the plant developmental stage (Ribeiro and Machado 2007; Ribeiro et al. 2009). Temperature is one of the variables with the greatest influence on $\mathrm{CO}_{2}$ assimilation in orange trees. The optimum temperature for photosynthesis of citrus species is between 25 and $30{ }^{\circ} \mathrm{C}$, and photosynthate production by orange trees considerably decreases at lower or higher temperatures (Medina et al. 2002; Ribeiro et al. 2004; Machado et al. 2005; Ribeiro and Machado 2007; Ribeiro et al. 2009; Magalhães Filho et al. 2009). Other studies have reported that maximum stomatal conductance in citrus species occurs at approximately $30{ }^{\circ} \mathrm{C}$, and maximum photosynthesis occurs between 22 and $25{ }^{\circ} \mathrm{C}$ (Machado et al. 2002).

Crop responses to increased atmospheric $\mathrm{CO}_{2}$ are not always positive because crops are affected by all environmental factors. The current $\mathrm{CO}_{2}$ levels limit $\mathrm{CO}_{2}$ assimilation in plants such as orange trees, and increasing atmospheric $\mathrm{CO}_{2}$ from 800 to $1000 \mathrm{ppm}$ stimulates photosynthesis (Amthor 2001). However, atmospheric $\mathrm{CO}_{2}$ levels close to $1000 \mathrm{ppm}$ have been reported to be excessive and cause phytotoxicity (Pinto et al. 2004).

Currently, there is considerable concern regarding the effects of climate change on crop yield, and there is a growing interest in understanding the processes, mechanisms, and factors within the soil-plant-atmosphere system that are affected by increases in atmospheric $\mathrm{CO}_{2}$ concentrations and changes in air temperature. Well-established models for the behavior of herbaceous crops in response to climate change already exist. This is the case of the AquaCrop model, which was developed based on the reevaluation and restructuring of bulletin 33 of the Food and Agriculture Organization of the United Nations (FAO; Doorenbos and Kassan 1979), with the goal of addressing drought and further improving water use efficiency (Steduto et al. 2009; Raes et al. 2009). However, for tree crops such as citrus trees, which have long life cycles, further studies of the responses to climate change are needed, and this may be achieved through modeling.

A comprehensive method connecting climate factors with the yield pattern of tree crops over the years is therefore necessary. This type of study fits perfectly in the system dynamics methodology, which is a new type of integrated analysis of chains of natural cyclical events (Capra 1996).

The objective of the present study was to develop a simulation model for growth responses to climate changes in sweet orange (Citrus sinensis L. Osbeck) cv. Natal, based on the principles of system dynamics, to investigate the effects of climate change/climate variability mediated by changes in atmospheric $\mathrm{CO}_{2}$ concentrations and variations in air temperature and to determine their implications on water use efficiency in citrus production in the region of São José do Rio Preto, São Paulo, Brazil.

\section{Materials and methods}

A dynamic simulation model for water use efficiency in citrus tree crops (ESM-Citrus) was developed using a system dynamics approach using the platform STELLA 10.0.5 (ISEE SYSTEMS 2001; 2009) A system analysis of citrus production and yield formation was 
performed, considering the existence in the literature of well-established models that simulate the production of herbaceous crops in response to climate change, such as the AquaCrop model (Steduto et al. 2009; Raes et al. 2009). Owing to the lack of simulation models for tree crops, the possibility of adapting existing models to tree crops by integrating data from previous studies has long been envisioned.

The initial steps included the identification of elements and processes involved in yield formation in citrus species in studies investigating the effects of climate changes, namely, changes in atmospheric $\mathrm{CO}_{2}$ concentrations, the relationships of atmospheric $\mathrm{CO}_{2}$ concentrations with air temperature, and their influence on water use efficiency in citrus production.

\subsection{Structuring of the simulation model of water use efficiency in citrus species (ESM-Citrus)}

The conceptual diagram presented in Fig. 1 illustrates the main variables involved in crop yield formation, based on which the present model was developed.

After identifying the main variables involved in yield formation and their inter-relations, a causal diagram, also called an influence or causal loop diagram, was built to represent the model's structure (Fig. 2).

The inter-relations among the main variables are presented in Fig. 2. The variables' water use efficiency and $\mathrm{CO}_{2}$ affect the main accumulations in the system. The reference evapotranspiration (ETo) and transpiration (Tr) quantitatively influence the behavior of the water use

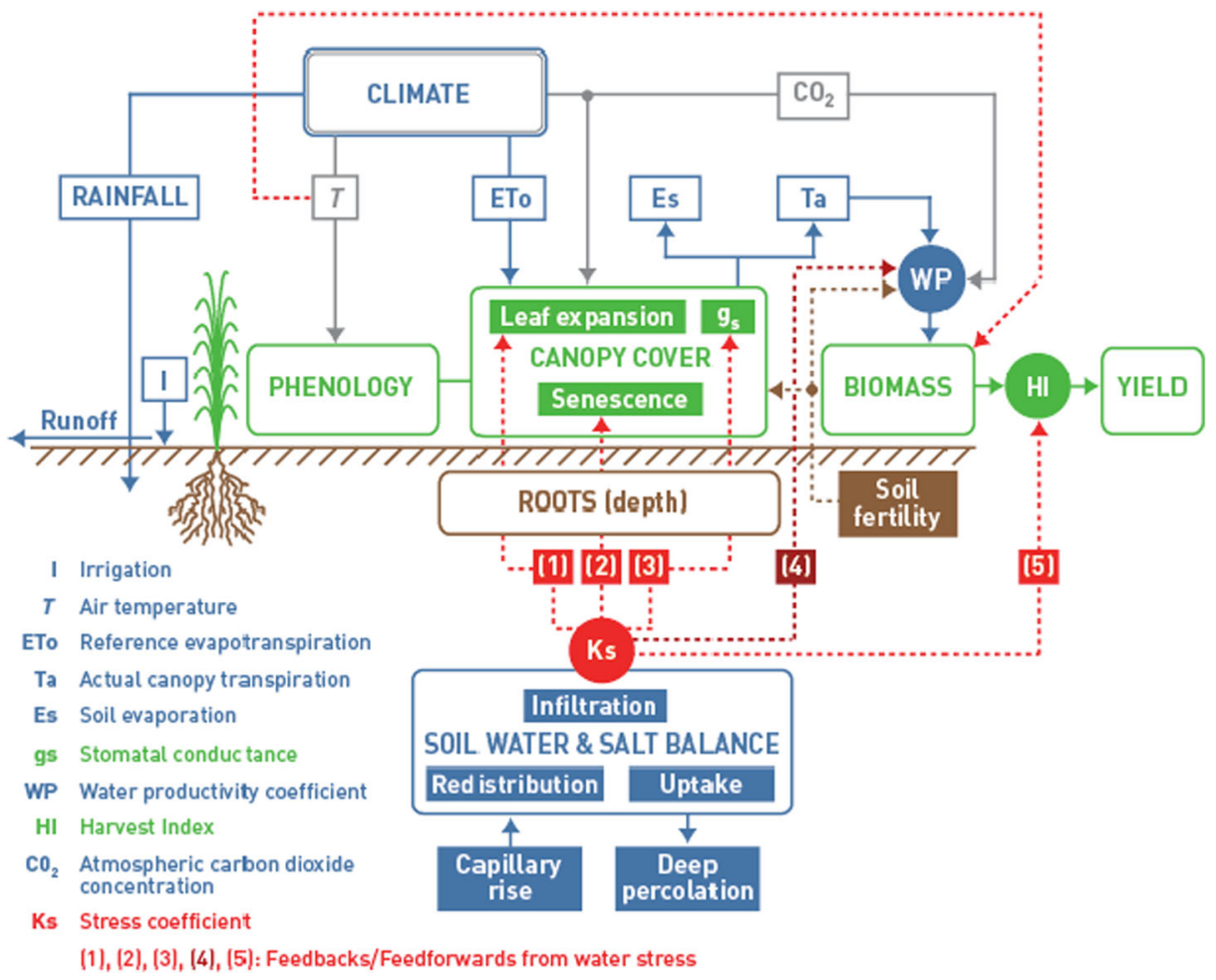

Fig. 1 Conceptual diagram of the process of yield formation (taken from FAO, Raes et al. 2012) 


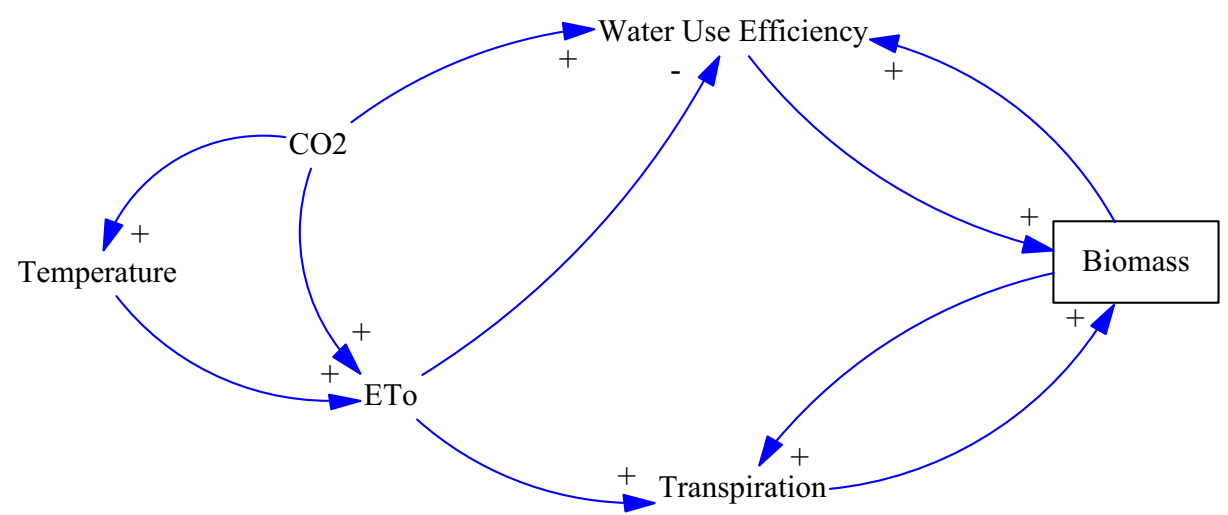

Fig. 2 Influence diagram for the developed model. Source: result of study obtained during the model's development

efficiency. Biomass is the main accumulated stock in the system. Water use efficiency and biomass receive water during yield formation. $\mathrm{CO}_{2}$ also strongly influences biomass formation and water use efficiency, as a substrate for carboxylation. ETo and Tr fill or empty the main stocks and therefore act as flows.

The feedback loops between system components can be described as follows: increased $\mathrm{CO}_{2}$ concentrations will result in increased water use efficiency (+). An increased transpiration rate will result in increased water use efficiency, and increased biomass will result in increased water use efficiency $(+)$. Increased reference evapotranspiration will result in decreased water use efficiency ( $(-)$. There is positive feedback between biomass and transpiration $(+)$.

Based on the causal loop diagram (Fig. 2), a stock and flow diagram was built (Fig. 3) to describe the functioning of the system in more detail, allowing mathematical simulations of water use efficiency in sweet orange cv. Natal.

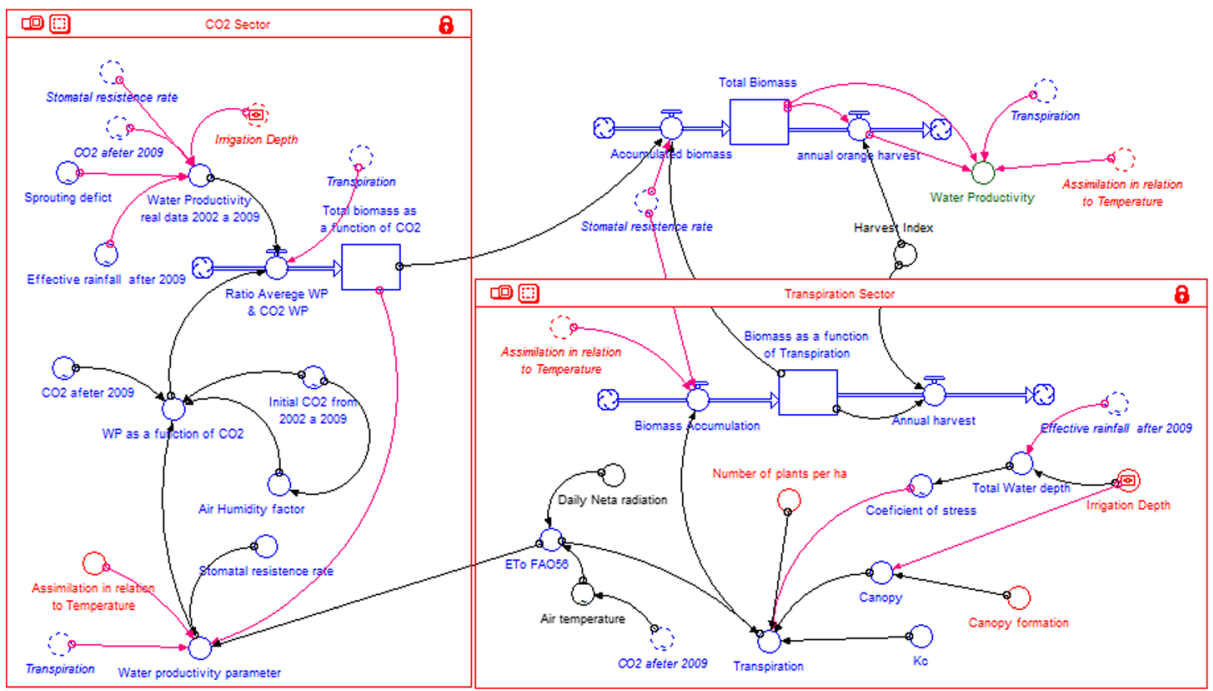

Fig. 3 Stock and flow diagram. Source: study result 


\subsection{Mathematical base for the development of ESM-Citrus}

The water use efficiency (WP) was calculated using the method described in studies published by the FAO (Steduto et al. 2007; Raes et al. 2009; Raes et al. 2012). Equations 1, 2, and 3 were essential for the calculation of WP and normalization of $\mathrm{CO}_{2}$ atmospheric concentrations for WP.

$$
W P=\left(\frac{\mathrm{B}}{\sum \frac{T r}{E T o}}\right)\left[\mathrm{CO}_{2}\right]
$$

where

$B \quad$ Total biomass, $\mathrm{g} \mathrm{m}^{-2}$, kilogram of biomass per square meter

WP Water productivity (water use efficiency), $\mathrm{g} \mathrm{m}^{-2}$, kilogram of biomass per square meter and per millimeter of water transpired, or kilogram of biomass per cubic meter of water transpired

$\operatorname{Tr} \quad$ Crop transpiration ( $\mathrm{mm})$

ETo Reference evapotranspiration ( $\mathrm{mm}$ )

$\mathrm{CO}_{2}$ Atmospheric $\mathrm{CO}_{2}$ concentration (ppm)

Transpiration was calculated according to Eq. 2 (Raes et al. 2009).

$$
\operatorname{Tr}=K s^{*} D * \% C C * K \operatorname{ctr} * E T o
$$

where

Ks Drought stress coefficient (decimal)

$\%$ CC Canopy cover (decimal)

$K \mathrm{c}_{\mathrm{Trx}} \quad$ Crop coefficient $(\mathrm{Kc})$ for maximum transpiration (non-dimensional)

ETo Reference evapotranspiration ( $\mathrm{mm}$ )

All complex $\mathrm{CO}_{2}$ fixation metabolic processes at the biochemical level are included in the parameters of Eqs. 3 and 4 (Steduto et al. 2007).

$$
W P=W P_{b} \frac{C_{a, o}}{C_{a}} * D
$$

where

WP Water use efficiency normalized for atmospheric $\mathrm{CO}_{2}$ concentration $\left(\mathrm{g} \mathrm{m}^{-2} \mathrm{~mm}^{-1}\right)$

$\mathrm{WP}_{\mathrm{b}}$ Biomass water use efficiency (calculated using the yields obtained from Citrosuco company) $\left(\mathrm{g} \mathrm{m}^{-2} \mathrm{~mm}^{-1}\right)$

$C_{\mathrm{a}, \text { o }}$ Annual mean atmospheric $\mathrm{CO}_{2}$ concentration measured at Mauna Loa Observatory (Hawaii) for the reference year

$C_{\mathrm{a}} \quad$ Annual mean atmospheric $\mathrm{CO}_{2}$ concentration measured at Mauna Loa Observatory (Hawaii) for the year when the biomass is produced

$D \quad$ Empirical factor approximating the sum of $\Delta w$, i.e., the sum of the difference in water vapor concentration between the intercellular space and the atmosphere for a given 
situation $(\Delta w)$ and a reference situation $\left(\Delta w_{\mathrm{o}}\right)$. Steduto et al. (2007) recommend calculating $D$ using Eq. 4 , where $C_{\mathrm{a}}$, o is the reference $\mathrm{CO}_{2}$ concentration of $360 \mathrm{ppm}$

$$
D=a-b \times\left(C_{\mathrm{a}}-C_{\mathrm{a}, \mathrm{o}}\right)
$$

where

$$
a=1 \text { and } b=0.000138 \text {. }
$$

The coefficients $a$ and $b$ in Eq. 4 were determined by Steduto et al. (2007), who performed experiments in environment chambers under controlled conditions of $\mathrm{CO}_{2}$ emissions, having normalized saturation water vapor pressure, air temperature, and humidity, among others. The authors suggested that with adaptations, Eq. 4 could be used for normalization for different atmospheric $\mathrm{CO}_{2}$ concentrations.

During model structuring, coefficients that enabled simulation of carboxylation in orange trees, namely, carboxylation rate as a function of temperature (Table 1), were included in the model, and a stomatal resistance coefficient of $23 \%$ was used (Machado et al. 2005). In addition to stomatal resistance, an inflection point was considered that established a $50 \%$ decrease in carboxylation starting at $600 \mathrm{ppm} \mathrm{CO}_{2}$. This inflection point was based on previous reports that atmospheric $\mathrm{CO}_{2}$ levels close to $1000 \mathrm{ppm}$ are excessive and cause phytotoxicity (Pinto et al. 2004; Streck and Alberto 2006; Streck 2005; Machado et al. 2005; Amthor 2001).

\subsection{Source of information used to test ESM-Citrus}

After building the model, yield data for consecutive years for sweet orange cv. Natal grown with and without irrigation were acquired and used to test whether the water use efficiency values simulated by the model were similar to those supplied by the FAO for $\mathrm{C}_{3}$ plants ( 15 to $20 \mathrm{~g} \mathrm{~m}^{-2} \mathrm{~mm}^{-1}$ ).

Data for sweet orange cv. Natal grown under two management systems, with or without irrigation, were used. Trees were planted in 1998, and yield data were collected beginning in 2002, when the orchards were 5 years old. The sweet orange cv. Natal was used in both cases, using the lemon cv. Cravo as rootstock. Cultivation was performed without irrigation in the Onda Verde municipality and with drip irrigation (flow rate $2 \mathrm{~L} \mathrm{~h}^{-1}$ ) in the municipality of Altair. The total annual depth of irrigation water applied (Table 1) varied, depending on the number of days with application of irrigation for 6,8 , or $10 \mathrm{~h}$, which in turn depended on the crop development stage and rainfall. The Citrosuco company, which supplied the yield data,

\begin{tabular}{|c|c|c|c|c|c|c|c|c|}
\hline & 2002 & 2003 & 2004 & 2005 & 2006 & 2007 & 2008 & 2009 \\
\hline$\sum$ ETo $(\mathrm{mm})^{\mathrm{a}}$ & 1566 & 1406 & 1414 & 1436 & 1403 & 1449 & 1382 & 1445 \\
\hline Irrigation $(\mathrm{mm})^{\mathrm{b}}$ & 793.6 & 769.6 & 795.2 & 809.6 & 798.4 & 644.8 & 788.8 & 710.4 \\
\hline Effective rainfall $^{\mathrm{c}}$ & 766.55 & 942.14 & 826.98 & 893.11 & 982.49 & 816.29 & 758.35 & 1064.56 \\
\hline Days with irrigation $^{\mathrm{b}}$ & 124 & 116 & 122 & 126 & 104 & 97 & 118 & 107 \\
\hline
\end{tabular}

Table 1 Total irrigation water depth applied in each year

\footnotetext{
${ }^{\mathrm{a}}$ IAC data bank

${ }^{\mathrm{b}}$ Citrosuco company

${ }^{\mathrm{c}}$ Effective rainfall calculated as proposed by the USDA Soil Conservation Service (USDA-SCS) using rainfall data supplied by the DAEE (Barbosa et al. 2005)
} 
determines the days of irrigation application considering the days of rainfall and applies irrigation during 90 to 130 days per agricultural year, depending on the climate. The company never applies irrigation in January, February, June, or December.

For the irrigated area, all evapotranspiration was replaced by irrigation, and therefore, the stress coefficient $\left(K_{\mathrm{s}}\right)$ was considered to be 1 . For the area without irrigation, the stress coefficient was calculated for each year using the value of rainfall, which was obtained as follows: the total irrigation water depth was considered as $100 \%$ of the evapotranspiration volume, i.e., 1. The percentage water stress for the conditions without irrigation was calculated using this value and the value of effective rainfall, which was the only water supplied to the area without irrigation.

Rainfall data for the two orchards, which were used as a basis for the model simulation, were obtained from the State of São Paulo Department of Waters and Electrical Power (Departamento de Águas e Energia Elétrica - DAEE). Potential evapotranspiration values were obtained from the management points of the Campinas Agronomic Institute (Instituto Agronômico de Campinas - IAC).

A crop coefficient $(K \mathrm{c})$ for maximum transpiration $\left(K \mathrm{c}_{\mathrm{Trx}}\right)$ during the phenological cycle of citrus trees of 0.85 was considered, as recommended by Doorenbos and Pruitt $(1984,1997)$.

\subsection{WP calculation}

The total biomass was calculated using the yield data for sweet orange cv. Natal supplied by the Citrosuco company. The yields corresponded to the useful biomass of sweet orange cv. Natal, the fruit itself, for both cultivation conditions (with and without irrigation). These values were converted into total biomass using a conversion factor based on previous studies that determined the percentage of orange trees that corresponded to useful biomass (Mattos Junior et al. 2003).

Canopy volume $(\mathrm{Vc})$ values for sweet orange cv. Natal trees for the years for which Citrosuco company supplied the yield data were calculated using values from previous reports (Quaggio et al. 2004; Graça et al. 2001; Stuchi and Donadio 2000; Ledo et al. 1999). With this information, it was established that the trees in the irrigated area had fully formed canopy volume $(100 \% \mathrm{Vc})$. For trees in the non-irrigated area, Vc was calculated considering the percent reduction value based on Levy et al. (1978) and Romero et al. (2006). Those studies reported that canopy volume is positively correlated with water consumption, indicating a need to use a reduction factor in the calculation of $\mathrm{Vc}$ for orange trees grown without irrigation. The percent reduction value used was based on Romero et al. (2006), who reported a $41 \%$ reduction in canopy volume of citrus trees grown under deficit irrigation.

Transpiration per plant was calculated using the canopy volume values. Transpiration per hectare for each agricultural year, with and without irrigation, was calculated using the transpiration per plant and the number of plants per hectare.

The steps to obtain the equations fed to the STELLA software were as follows: the data supplied by Citrosuco company were analyzed, and some variables were observed to affect plant yield, namely, the water deficit occurring during the sprouting stage (WDS) of sweet orange cv. Natal that resulted from climate conditions and the stage of the crop cycle. Water deficit was determined by calculating the water balance for the period corresponding to the yield data (2002 to 2009).

The highest annual water deficit occurred between the second half of May and mid-August. During that period, in the area with irrigation, the water lost by evapotranspiration was 
replaced by irrigation. From an analysis of the yield data under the two cultivation conditions (with and without irrigation), a multiple linear correlation equation was built for each condition. The multiple linear correlation for the area with irrigation is expressed in Eq. 5.

$$
\mathrm{WP}=-480.76-0.084 * \mathrm{WDS}+1.31 * \mathrm{CO}_{2}-0.007 * I
$$

where

WP Water productivity $\left(\mathrm{g} \mathrm{m}^{-2} \mathrm{~mm}^{-1}\right)$;

WDS Water deficit during sprouting (mm); application range (70 $\leq$ WDS $\leq 400)$

$\mathrm{CO}_{2} \quad$ Atmospheric $\mathrm{CO}_{2}$ concentration (ppm); application range $\left(280 \leq \mathrm{CO}_{2} \leq 1200\right)$

I Water irrigation depth applied during the crop cycle $(\mathrm{mm})$; application range $(600 \leq I \leq 900)$

The three variables included in Eq. 5 explained $77 \%$ of the WP variability of the real yield data recorded between 2002 and $2009\left(R^{2}=0.77\right)$.

The multiple correlations for the area without irrigation is expressed in Eq. 6;

$$
\mathrm{WP}=-10.24-0.03 * \mathrm{WDS}+0.04 * \mathrm{ER}
$$

where

WP Water productivity $\left(\mathrm{g} \mathrm{m}^{-2} \mathrm{~mm}^{-1}\right)$;

WDS Water deficit during sprouting (mm); application range $(70 \leq \mathrm{WDS} \leq 400)$;

ER Effective rainfall $(\mathrm{mm}) ;(600 \leq \mathrm{ER} \leq 1000)$

The two variables included in Eq. 6 (water deficit during sprouting and effective rainfall) explained $96 \%$ of the WP variability without irrigation $\left(R^{2}=0.96\right)$.

Equations 5 and 6 were fed to the STELLA software as model input variables. Simulations were run in STELLA using the real yield values obtained for the areas with and without irrigation.

Water use efficiency variations in response to changes in air temperature were simulated using $\mathrm{CO}_{2}$ assimilation response curves obtained by Machado et al. (2005) at different air temperatures using chambers with controlled conditions of air temperature and different $\mathrm{CO}_{2}$ concentrations (Table 2). The authors reported a stomatal control of photosynthesis coefficient of $23 \%$.

The model included additional parameters in its structure that were also essential. The water deficit included in the model was obtained from Marengo (2006), who modeled the behavior of rainfall until 2100. This was used to estimate the future behavior of water deficit. The input data used in the model are presented in Table 3.

\begin{tabular}{|c|c|c|c|}
\hline Temperature $\left({ }^{\circ} \mathrm{C}\right)$ & $25^{\circ} \mathrm{C}$ & $30^{\circ} \mathrm{C}$ & $40^{\circ} \mathrm{C}$ \\
\hline Assimilation percentage $(\%)$ & 81.37 & 93.01 & 59.96 \\
\hline Annual amount of $\mathrm{CO}_{2}$ assimilation $\left(\mathrm{g} \mathrm{m}^{-2}\right.$ year $\left.{ }^{-1}\right)$ & 527.40 & 648.15 & 388.61 \\
\hline
\end{tabular}

Table 2 Annual $\mathrm{CO}_{2}$ assimilation rate as a function of air temperature

Source: adapted from Machado et al. (2005) 
The characteristics of the nine scenarios with irrigation and the nine scenarios without irrigation used in the model simulations are presented in Table 4.

\section{Results and discussion}

All atmospheric $\mathrm{CO}_{2}$ concentration projections by the IPCC used in the present study indicate increases in atmospheric $\mathrm{CO}_{2}$ concentrations between 2010 and 2100 (sustainable-SUST 387544 ppm; maximum-MAX 413-1142 ppm; minimum-MIN 366-794 ppm). The simulations obtained using the present model exhibited increased water productivity with the highest atmospheric $\mathrm{CO}_{2}$ concentrations, both with and without irrigation. $\mathrm{CO}_{2}$ is the primary substrate of photosynthesis in plants, and increased atmospheric $\mathrm{CO}_{2}$ concentrations result in increased plant growth rates; furthermore, this beneficial effect of higher $\mathrm{CO}_{2}$ concentrations is more pronounced in $\mathrm{C}_{3}$ plants, such as citrus species (Taiz and Zeiger 1991) (Table 5).

The developed model revealed higher water productivity for all $\mathrm{CO}_{2}$ concentrations projected by the IPCC and higher decreases in $\mathrm{CO}_{2}$ assimilation rates in response to rising air temperature in the area without irrigation (scenarios A through I) compared with the irrigated area (scenarios J through R) (Table 5).

For $25{ }^{\circ} \mathrm{C}$ and $30{ }^{\circ} \mathrm{C}$, the WP was higher for the MAX than for the SUST and MIN $\mathrm{CO}_{2}$ concentration levels, both without (scenarios $\mathrm{A}$ and $\mathrm{B}, \mathrm{D}$ and $\mathrm{E}, \mathrm{G}$ and $\mathrm{H}$ ) and with irrigation (scenarios $\mathrm{J}$ and $\mathrm{K}, \mathrm{M}$ and $\mathrm{N}, \mathrm{P}$ and $\mathrm{Q}$ ). For $40^{\circ} \mathrm{C}$, the $\mathrm{CO}_{2}$ assimilation was highest with the highest atmospheric $\mathrm{CO}_{2}$ concentrations (scenarios C, F, I, L, O and R; Table 5).

The continuous increase in atmospheric $\mathrm{CO}_{2}$ has been considered to have positive effects on agriculture (Streck and Alberto 2006; Streck 2005). This is because $\mathrm{CO}_{2}$ is the primary substrate of photosynthesis, the process through which $\mathrm{CO}_{2}$ is fixed and converted to carbohydrates via the Calvin cycle, and its increase results in increased plant growth rates (Taiz and Zeiger 2004). This is common to $\mathrm{C}_{4}$ and $\mathrm{C}_{3}$ plants, such as orange trees (Zhang and Dang 2005; Ainsworth and Long 2005; Streck and Alberto 2006; Streck 2005).

Table 3 Description of the variables used to build the model-input data

\begin{tabular}{|c|c|}
\hline Variables & Characteristics \\
\hline $\begin{array}{l}\text { Annual } \mathrm{CO}_{2} \text { assimilation as a function of } \\
\text { air temperature (decimal) }\end{array}$ & $\begin{array}{l}\text { Three temperatures, } 25^{\circ} \mathrm{C}, 30^{\circ} \mathrm{C} \text {, and } 40^{\circ} \mathrm{C} \text { corresponding to } 0.2 \text {, } \\
0.1 \text {, and } 0.4 \text {, respectively }\end{array}$ \\
\hline Rainfall (mm) & $\begin{array}{l}\text { Overall mean }(865 \mathrm{~mm}) \text { calculated for the period from } 2002 \text { to } 2009 \\
\text { and considering the rainfall behavior reported by Marengo (2006) }\end{array}$ \\
\hline Water deficit (mm) & $\begin{array}{l}\text { Overall mean }(57.76 \mathrm{~mm}) \text {, which was obtained by calculating the } \\
\text { water balance for the years for which plant yields were obtained } \\
\text { ( } 2002 \text { to } 2009) \text {. In simulations, an initial water deficit of } 54 \mathrm{~mm} \\
\text { was considered for } 2010 \text {, which was gradually increased up to } \\
74 \mathrm{~mm} \text { in } 2100 \text {, based on Marengo (2006) }\end{array}$ \\
\hline Stomatal resistance (decimal) & 0.23 (Machado et al. 2005) \\
\hline Canopy volume (decimal) & 1.0 with irrigation and 0.59 without irrigation (Romero et al. 2006) \\
\hline Water irrigation depth & $\begin{array}{l}\text { Overall mean }(775 \mathrm{~mm}) \text { calculated from the irrigation data supplied } \\
\text { by Citrosuco company for the period from } 2002 \text { to } 2009\end{array}$ \\
\hline $\mathrm{CO}_{2}(\mathrm{ppm})$ & $\begin{array}{l}\text { Three atmospheric } \mathrm{CO}_{2} \text { concentrations (SUST, MIN, and MAX) } \\
\text { projected by the IPCC }\end{array}$ \\
\hline Inflection point & $\begin{array}{l}50 \% \text { decrease in carboxylation at } 600 \mathrm{ppm} \mathrm{CO}_{2} \text { based on Pinto et al. } \\
\text { (2004), Streck and Alberto (2006), Streck (2005), Machado et al. } \\
\text { (2005), and Amthor (2001) }\end{array}$ \\
\hline
\end{tabular}


Table 4 Scenarios proposed and evaluated in the present study

\begin{tabular}{ll}
\hline Scenarios & Description of the scenarios for the without irrigation area \\
A & Temperature $25^{\circ} \mathrm{C}, \mathrm{CO}_{2}$ in sustainable atmosphere $(387-544) \mathrm{ppm}$ \\
$\mathrm{B}$ & Temperature $30^{\circ} \mathrm{C}, \mathrm{CO}_{2}$ in sustainable atmosphere $(387-544) \mathrm{ppm}$ \\
$\mathrm{C}$ & Temperature $40^{\circ} \mathrm{C}, \mathrm{CO}_{2}$ in sustainable atmosphere $(387-544) \mathrm{ppm}$ \\
$\mathrm{D}$ & Temperature $25^{\circ} \mathrm{C}, \mathrm{CO}_{2}$ in maximum atmosphere $(413-1142) \mathrm{ppm}$ \\
$\mathrm{E}$ & Temperature $30^{\circ} \mathrm{C}, \mathrm{CO}_{2}$ in maximum atmosphere $(413-1142) \mathrm{ppm}$ \\
$\mathrm{F}$ & Temperature $40^{\circ} \mathrm{C}, \mathrm{CO}_{2}$ in maximum atmosphere $(413-1142) \mathrm{ppm}$ \\
$\mathrm{G}$ & Temperature $25^{\circ} \mathrm{C}, \mathrm{CO}_{2}$ in minimum atmosphere $(413-794) \mathrm{ppm}$ \\
$\mathrm{H}$ & Temperature $30^{\circ} \mathrm{C}, \mathrm{CO}_{2}$ in minimum atmosphere $(413-794) \mathrm{ppm}$ \\
$\mathrm{I}$ & Temperature $40^{\circ} \mathrm{C}, \mathrm{CO}_{2}$ in minimum atmosphere $(413-794) \mathrm{ppm}$ \\
Scenarios & Description of the $\mathrm{Scenarios}^{-73}$ for the irrigated area \\
$\mathrm{J}$ & Temperature $25^{\circ} \mathrm{C}, \mathrm{CO}_{2}$ in sustainable atmosphere $(387-544) \mathrm{ppm}$ \\
$\mathrm{K}$ & Temperature $30^{\circ} \mathrm{C}, \mathrm{CO}_{2}$ in sustainable atmosphere $(387-544) \mathrm{ppm}$ \\
$\mathrm{L}$ & Temperature $40^{\circ} \mathrm{C}, \mathrm{CO}_{2}$ in sustainable atmosphere $(387-544) \mathrm{ppm}$ \\
$\mathrm{M}$ & Temperature $25^{\circ} \mathrm{C}, \mathrm{CO}_{2}$ in maximum atmosphere $(413-1142) \mathrm{ppm}$ \\
$\mathrm{N}$ & Temperature $30^{\circ} \mathrm{C}, \mathrm{CO}_{2}$ in maximum atmosphere $(413-1142) \mathrm{ppm}$ \\
$\mathrm{O}$ & Temperature $40^{\circ} \mathrm{C}, \mathrm{CO}_{2}$ in maximum atmosphere $(413-1142) \mathrm{ppm}$ \\
$\mathrm{P}$ & Temperature $25^{\circ} \mathrm{C}, \mathrm{CO}_{2}$ in minimum atmosphere $(413-794) \mathrm{ppm}$ \\
$\mathrm{Q}$ & Temperature $30^{\circ} \mathrm{C}, \mathrm{CO}_{2}$ in minimum atmosphere $(413-794) \mathrm{ppm}$ \\
$\mathrm{R}$ & Temperature $40^{\circ} \mathrm{C}, \mathrm{CO}_{2}$ in minimum atmosphere $(413-794) \mathrm{ppm}$ \\
\hline
\end{tabular}

The water use efficiency was higher with irrigation than without irrigation (Table 5). Without irrigation, the highest water productivity was $27.69 \mathrm{~g} \mathrm{~m}^{-2} \mathrm{~mm}^{-1}$ for 2100 , which was observed for scenario B. Scenario K, with irrigation, exhibited the same characteristics as scenario $\mathrm{B}$ and presented water productivity of $59.1 \mathrm{~g} \mathrm{~m}^{-2} \mathrm{~mm}^{-1}$.

The developed model gathers the variables involved in water productivity of sweet orange cv. Natal, in an attempt to understand how environmental factors, air temperature, and $\mathrm{CO}_{2}$

Table 5 Water productivity of sweet orange cv. Natal under different scenarios

\begin{tabular}{|c|c|c|c|c|c|c|c|c|c|c|c|}
\hline Scenarios & $\mathrm{CO}_{2}$ & Temperature ${ }^{\circ} \mathrm{C}$ & 2020 & 2030 & 2040 & 2050 & 2060 & 2070 & 2080 & 2090 & 2100 \\
\hline \multicolumn{12}{|c|}{ Water productivity of sweet orange $\mathrm{cv}$. Natal without irrigation area WP $\mathrm{g} \mathrm{m}^{-2} \mathrm{~mm}^{-1}$} \\
\hline A & SUST & $25^{\circ} \mathrm{C}$ & 10.92 & 13.71 & 15.87 & 17.66 & 19.2 & 20.57 & 21.82 & 22.97 & 23.95 \\
\hline B & & $30^{\circ} \mathrm{C}$ & 12.7 & 15.91 & 18.4 & 20.46 & 22.23 & 23.8 & 25.23 & 26.56 & 27.69 \\
\hline $\mathrm{C}$ & & $40^{\circ} \mathrm{C}$ & 10.1 & 12.74 & 14.77 & 16.46 & 17.91 & 19.2 & 20.38 & 21.47 & 22.39 \\
\hline $\mathrm{D}$ & MAX & $25^{\circ} \mathrm{C}$ & 10.57 & 13.19 & 15.14 & 8.34 & 8.95 & 9.46 & 9.88 & 10.23 & 10.51 \\
\hline $\mathrm{E}$ & & $30^{\circ} \mathrm{C}$ & 12.3 & 15.32 & 17.55 & 9.65 & 10.36 & 10.94 & 11.42 & 11.83 & 12.15 \\
\hline $\mathrm{F}$ & & $40^{\circ} \mathrm{C}$ & 9.77 & 12.25 & 14.08 & 7.76 & 8.34 & 8.81 & 9.21 & 9.54 & 9.8 \\
\hline $\mathrm{G}$ & MIN & $25^{\circ} \mathrm{C}$ & 10.39 & 13.1 & 15.18 & 16.88 & 18.28 & 19.46 & 10.23 & 10.66 & 10.99 \\
\hline $\mathrm{H}$ & & $30^{\circ} \mathrm{C}$ & 13.05 & 16.36 & 18.9 & 20.97 & 22.7 & 24.14 & 12.68 & 13.21 & 13.62 \\
\hline I & & $40^{\circ} \mathrm{C}$ & 10.06 & 12.86 & 14.98 & 16.7 & 18.12 & 19.32 & 10.17 & 10.6 & 10.94 \\
\hline \multicolumn{12}{|c|}{ Water productivity of sweet orange $\mathrm{cv}$. Natal with irrigation WP $\mathrm{g} \mathrm{m}^{-2} \mathrm{~mm}^{-1}$} \\
\hline $\mathrm{J}$ & SUST & $25^{\circ} \mathrm{C}$ & 14.56 & 20.31 & 25.98 & 31.57 & 37 & 42.19 & 47.1 & 51.73 & 55.65 \\
\hline $\mathrm{K}$ & & $30^{\circ} \mathrm{C}$ & 15.55 & 21.64 & 27.64 & 33.56 & 39.32 & 44.82 & 50.03 & 54.94 & 59.1 \\
\hline $\mathrm{L}$ & & $40^{\circ} \mathrm{C}$ & 12.38 & 17.37 & 22.29 & 27.15 & 31.86 & 36.36 & 40.62 & 44.63 & 48.04 \\
\hline M & MAX & $25^{\circ} \mathrm{C}$ & 18.95 & 25.8 & 32.71 & 19.83 & 23.29 & 26.7 & 30.03 & 33.25 & 36.08 \\
\hline $\mathrm{N}$ & & $30^{\circ} \mathrm{C}$ & 20.32 & 27.57 & 34.88 & 21.12 & 24.79 & 28.4 & 31.93 & 35.35 & 38.35 \\
\hline $\mathrm{O}$ & & $40^{\circ} \mathrm{C}$ & 16.08 & 22.07 & 28.09 & 17.07 & 20.07 & 23.02 & 25.91 & 28.7 & 31.15 \\
\hline $\mathrm{P}$ & MIN & $25^{\circ} \mathrm{C}$ & 9.58 & 14.83 & 20.65 & 26.75 & 33.03 & 39.41 & 22.91 & 26.09 & 28.88 \\
\hline Q & & $30^{\circ} \mathrm{C}$ & 10.19 & 15.75 & 21.93 & 28.4 & 35.06 & 41.83 & 24.32 & 27.69 & 30.65 \\
\hline $\mathrm{R}$ & & $40^{\circ} \mathrm{C}$ & 8.14 & 12.68 & 17.73 & 23.01 & 28.44 & 33.96 & 19.76 & 22.51 & 24.93 \\
\hline
\end{tabular}

$\mathrm{CO}_{2}$ concentrations projected by the IPCC, SUST sustainable (387-544 ppm), MAX maximum (413-1142 ppm), $M I N$ minimum (413-794 ppm), WP water productivity parameter $\left(\mathrm{g} \mathrm{m}^{-2} \mathrm{~mm}^{-1}\right)$ 
concentrations affect the plant biomass accumulation and thus water use efficiency, of orange trees over time. It should be noted that the highest water productivity (gram of plant biomass per millimeter water transpired) values were observed for $30{ }^{\circ} \mathrm{C}$ air temperature, both with and without irrigation, being $59.1 \mathrm{~g} \mathrm{~m}^{-2} \mathrm{~mm}^{-1}$ for 2100 under maximum atmospheric $\mathrm{CO}_{2}$ concentration (scenario E in Table 5). This result is in accordance with Machado et al. (2005), who studied the sweet orange cultivars Valencia, Murcote, and Tahiti and observed higher $\mathrm{CO}_{2}$ assimilation rates between 25 and $30{ }^{\circ} \mathrm{C}$, decreasing at air temperatures above $30{ }^{\circ} \mathrm{C}$. The data from that study were fundamental for the composition of the scenarios tested in the present study because negative effects on stomatal conductance under extreme temperatures $\left(15\right.$ and $\left.40{ }^{\circ} \mathrm{C}\right)$, which resulted in decreased photosynthetic rates, were reported.

Martinez et al. (2014) subjected forage plants to a temperature increase of $2{ }^{\circ} \mathrm{C}$, which was also based on the scenarios predicted by the IPCC, and observed that the temperature increase predicted to occur until 2050 could have beneficial effects on the physiology and biochemical and biophysical processes involved in forage plant growth. Furthermore, in that study, a 32\% increase in leaf area and $16 \%$ increase in shoot biomass were observed when compared to plants grown under normal conditions. The model for the growth of sweet orange cv. Natal developed in the present study that used a combination of scenarios of increased air temperature and carbon dioxide concentrations predicted increases in water use efficiency. This is mainly because the model considered increased biomass production up to $30{ }^{\circ} \mathrm{C}$ and $600 \mathrm{ppm}$ $\mathrm{CO}_{2}$. If increases in $\mathrm{CO}_{2}$ concentration are accompanied by increased air temperature, the crop growth and yield may not increase (Taiz and Zeiger 2004; Taiz and Zeiger 1991; Streck 2005, Siqueira et al. 2001). This may be due to the negative effects of increased atmospheric $\mathrm{CO}_{2}$ concentrations on citrus productivity (Allen and Vu 2009; Idso and Kimball 1991; Ribeiro and Machado 2007; Ribeiro et al. 2009; Magalhães Filho et al. 2009).

Other studies that used modeling to predict the impacts of climate change on agricultural yields also indicated decreased yields with high levels of atmospheric $\mathrm{CO}_{2}$ due to the simultaneous increase in temperature. The model by Krishnan et al. (2007) predicted a decrease in rice production of approximately $56 \%$ with $700 \mathrm{ppm} \mathrm{CO}_{2}$ and an air temperature increase of $4{ }^{\circ} \mathrm{C}$. The United Nations (2013) used the conceptual base of the FAO programs CropWat and AquaCrop to generate equations to predict potato and corn yields mediated by variability and/or climate changes in Colombia and concluded that the use of modeling, in addition to being useful for yield predictions, made it possible to model the photosynthetic response of each crop to environmental conditions.

The simulations performed for 2020 through 2100 indicated a gradual increase in plant biomass produced (g) per millimeter water transpired in sweet orange cv. Natal with increased atmospheric $\mathrm{CO}_{2}$. This was the main result of the model developed. However, previous studies have found that if increased $\mathrm{CO}_{2}$ concentrations occur together with increased water vapor deficit, both transpiration rates and $\mathrm{CO}_{2}$ assimilation will be negatively affected, thereby decreasing plant growth and thus water productivity (Medina et al. 1998, 1999; Machado et al. 2005).

Other studies also reported more pronounced decreases in photosynthesis rates in orange trees with decreased soil water content (Medina et al. 1998, 1999). Under drought conditions, there is stomatal closure to limit water vapor loss to the atmosphere, resulting in decreased $\mathrm{CO}_{2}$ assimilation and plant productivity (Medina et al. 1998).

Martin et al. (1995) studied the responses of lemon plants to high $\mathrm{CO}_{2}$ concentrations combined with high and low temperatures and observed that high $\mathrm{CO}_{2}$ concentrations combined with high temperatures $\left(42{ }^{\circ} \mathrm{C}\right.$ day $/ 32{ }^{\circ} \mathrm{C}$ night) resulted in $87 \%$ increased growth, 
whereas the same $\mathrm{CO}_{2}$ concentrations combined with lower temperatures $\left(29{ }^{\circ} \mathrm{C}\right.$ day $/ 21{ }^{\circ} \mathrm{C}$ night) only increased growth by $21 \%$.

\section{Conclusions}

The developed model graphically and mathematically represents the responses to climate changes of the processes involved in water use efficiency in sweet orange cv. Natal. Citrus crop yields will increase up to $600 \mathrm{ppm}$ atmospheric $\mathrm{CO}_{2}$ and $30{ }^{\circ} \mathrm{C}$ air temperature, but they will decrease at higher temperatures and $\mathrm{CO}_{2}$ concentrations.

Increased atmospheric $\mathrm{CO}_{2}$ concentrations will have a positive effect on $\mathrm{CO}_{2}$ assimilation in orange trees, resulting in increased biomass produced $(\mathrm{g})$ per millimeter of water transpired. However, this positive effect may be masked by other effects of $\mathrm{CO}_{2}$ increases, especially those associated with air temperature and water vapor deficit.

Acknowledgments The authors thank CAPES (Projeto MES-CUBA - 177/2012) for the financial support and scholarships awarded.

\section{References}

Ainsworth EA, Long SP (2005) What have we learned from 15 years of free-air $\mathrm{CO}_{2}$ enrichment (FACE)? A meta-analytic review of the responses of photosynthesis, canopy properties and plant production to rising $\mathrm{CO}_{2}$. New Phytologist, Oxford 165:351-372

Allen LH, Vu JCV (2009) Carbon dioxide and high temperature effects on growth of young orange trees in a humid, subtropical environment. Agricultural and Forest Meteorology, Amsterdam 149(5):820-830, may

Amthor JS (2001) Effects of atmospheric $\mathrm{CO}_{2}$ concentration on wheat yield: review of results from experiments using various approaches to control $\mathrm{CO}_{2}$ concentration. Field Crops Research, Amsterdam 73:1-34

Barbosa FC et al (2005) Espacialização da evapotranspiração de referência e precipitação efetiva para estimativa das necessidades de irrigação na região do Baixo Jaguaribe-CE. Revista Ciência Agronômica, Fortaleza 36(1):24-33

Capra F (1996) The web of life. New York: Anchor 347 p. CENTRO DE PESQUISAS METEOROLÓGICAS E CLIMÁTICAS APLICADAS A AGRICULTURA - CEPAGRI. Altair. Available:. Acess: abr. 2015

Delgado ARS et al (2010) Modelagem matemática para otimização da produção e renda de melão e melancia em função de lâminas de água e doses de nitrogênio. Irriga, Botucatu 15(1):1-9

Doorenbos I, Kassan AH (1979) Yield response to water. FAO, Roma 193 p. (FAO. Irrigation Drainage Paper, 33)

Doorenbos J, Pruitt WO (1984) Guidelines for predicting crop water requirements. Rome, FAO

Doorenbos I, Pruitt WO (1997) Las necessidades de agua de los cultivos. Estudio FAO Riego y Drenaje, Roma, n. 24. 144p. (FAO. Botelin Irrigation y Drenaje, 24)

Graça J et al (2001) Porta-enxertos para laranja 'Natal' no norte fluminense. LARANJA, Cordeirópolis 22(2):449-456

Idso SB, Kimball BA (1991) Downward regulation of photosynthesis and growth at high $\mathrm{CO}_{2}$ levels. No evidence for either phenomenon in three-year study of sour orange trees. Plant Physiology, Rockville 96:990-992

Intergovernmental Panel on Climate Changes - IPCC (2014) Climate Change 2014: Synthesis Report. Contribution of working groups I, II and III to the fifth assessment report of the intergovernmental panel on climate change [CORE WRITING TEAM, R.K. PACHAURI AND L.A. MEYER (Ed.)]. IPCC, Geneva, Switzerland, 151 p. Available at: <http://www.ipcc.ch/pdf/assessment-report/ar5/syr/SYR_AR5_FINAL_ full.pdf>. Acess in: 04 out. 2015

Krishnan $\mathrm{P}$ et al (2007) Impact of elevated $\mathrm{CO}_{2}$ and temperature on rice yield and methods of adaptation as elevated by crop simulation studies. Agriculture Ecosystems \& Environment, Amsterdam 122:233-242

Ledo AS et al (1999) Porta-enxertos para laranjeiras-doces (Citrus sinenses (L.) OSB.), em Rio Branco, Acre. Pesquisa Agropecuária Brasileira, Brasília 34(7):1211-1216

Levy Y, Bielorai H, Shalhevet J (1978) Long-term effects of different irrigation regimes on grapefruit tree development and yield. Journal of the American Society for Horticultural Science, Alexandria 103(5):680683 
Machado EC et al (2002) Variaação sazonal da fotossíntese, condutância estomática e potencial da água na folha de laranjeira 'Valência'. Scientia Agricola 59 (1):53-58

Machado EC et al (2005) Respostas da fotossíntese de três espécies de citros a fatores ambientais. Pesquisa Agropecuária Brasileira, Brasília 40:1161-1170

Magalhães Filho et al (2009) Variação da temperatura do substrato e fotossíntese em mudas de laranjeira 'Valência'. Pesquisa Agropecuária Brasileira, Brasília 44(9):1118-1126

Marengo JA (2006) Mudanças climáticas globais e seus efeitos sobre a biodiversidade — caracterização do clima atual e definição das alterações climáticas para o território brasileiro ao longo do século XXI. 2. ed, vol 1. Ministério do Meio Ambiente, Brasília, p 214

Martin CA et al (1995) Grow and topological changes of Citrus limon (L.) Burm. F. 'Eureka' in response to high temperatures and elevated atmospheric Carbon Dioxide. Journal of the American Society of Horticultural Science, Alexandria 120(6):1025-1031

Martinez et al (2014) Moderate warming increases PSII performance, antioxidant scavenging systems and biomass production in Stylosanthes capitata Vogel. Environmental and Experimental Botany, Kidlington, Oxford, England 102:58-67

Mattos Junior D et al (2003) Nutrient content of biomass components of Hamlin sweet orange trees. Scientia Agrícola, Piracicaba 60:155-160

Medina CL, Machado EC, Pinto JM (1998) Fotossíntese de laranjeira 'Valência' enxertada sobre quatro portaenxertos e submetida à deficiência hídrica. Bragantia, Campinas 57:1-14

Medina CL, Machado EC, Gomes MMA (1999) Condutância estomática, transpiração e fotossíntese em laranjeira 'Valência' sob deficiência hídrica. Revista Brasileira de Fisiologia Vegetal, Londrina 11(1):29-34

Medina CL et al (2002) Photosynthetic response of citrus grown under reflective aluminized polypropylene shading nets. Scientia Horticulturae, Amsterdam 96:115-125

Pinto HS, Assad ED, Zullo J Jr (2004) O aquecimento global e a agricultura. Revista Saneas, São Paulo 18:34-37

Quaggio JA et al (2004) Sweet orange trees grafted on selected rootstocks fertilized with nitrogen, phosphorus and potassium. Pesquisa Agropecuária Brasileira, Brasília 39(1):55-60

Raes D et al. (2009) Aquacrop: the FAO crop model to simulate yield response to water. In: FAO. AquaCrop. Version 4.0. Roma. Chap. 1

Raes D et al. (2012) Calculation procedures. In: FAO. AquaCrop. Version 4.0. Roma. Chap. 3

Ribeiro RV, Machado EC (2007) Some aspects of citrus ecophysiology in subtropical climates: re-visiting photosynthesis under natural conditions. Brazilian Journal of Plant Physiology, Campinas 19:393-411

Ribeiro RV, Machado EC, Oliveira RF (2004) Growth- and leaf-temperature effects on photosynthesis of sweet orange seedlings infected with Xylella fastidiosa. Plant Pathology, Chichester 53:334-340

Ribeiro RV et al (2009) Seasonal and diurnal changes in photosynthetic limitation of young sweet orange trees. Environmental and Experimental Botany, Amsterdam 66:203-211

Romero P et al (2006) Deficit irrigation and rootstock: their effects on water relations, vegetative development, yield, fruit quality and mineral nutrition of Clemenules mandarin. Tree physiology, Oxford 26:1537-1548

Siqueira OJW, Steinmetz S, de Salles LAB (2001) Efeitos potenciais das mudanças climáticas na agricultura brasileira e estratégias adaptativas para algumas culturas. In: Lima MA, Cabral OMR, Miguez JDG (eds) Mudanças climáticas globais e a agropecuária brasileira. Embrapa Meio Ambiente, Jaguariúna, pp 33-63

Steduto P, Hsiao TC, Fereres E (2007) On the conservative behavior of biomass water productivity. Irrigation Science, Heidelberg 25(3):189-207

Steduto P et al (2009) AquaCrop - the FAO crop model to simulate yield response to water: I. Concepts and underlying principles. Agronomy Journal, Madison 101(3):426

STELLA (2001) Introduction to systems thinking. High Performance Systems, Lebanon, 165p

STELLA 10.0.5. software (2009) Isee Systems, Lebanon

Stich S et al (2008) Evaluation of the terrestrial carbon cycle future plant geograph and climate-carbon cycle feedbacks using five dynamics global vegetation models (DGVMs). Glob Chang Biol 14(9):1-25

Streck NA (2005) Climate change and agroecosystems: the effect of elevated atmosferic $\mathrm{CO}_{2}$ and temperature on crop growth, development, and yield. Ciência Rural, Santa Maria 35:734-744

Streck NA, Alberto CM (2006) Estudo numérico do impacto da mudança climática sobre o rendimento de trigo, soja e milho. Pesquisa Agropecuária Brasileira, Brasília 41(9):1351-1359

Stuchi ES, Donadio LC (2000) Laranjeira folha murcha. Funep, Jaboticabal

Taiz L, Zeiger E (1991) Plant physiology. Benjamin/ Cummings Pub. Co., Redwood City, 559p

Taiz L, Zeiger E (2004) Fisiologia vegetal. 3.ed. Artemed, Porto Alegre, 719p

United Nations-ONU (2013) Desarrollo de una función agroclimática para estimar la productividad de los cultivos agrícolas em Colombia. Santiago de Chile (Médio Ambiente y desarrollo, 197)

Zhang S, Dang Q (2005) Effects of soil temperature and elevated atmospheric $\mathrm{CO}_{2}$ concentration on gas exchange, in vivo carboxylation and chlorophyll fluorescence in jack pine and white birch seedlings. Tree Physiology, Oxford 25:523-531 